Vol. 5, No. 1, 2018

UDC 368

\author{
A. Ostrowska-Dankiewicz \\ $\mathrm{PhD}$, Assistant Professor \\ Rzeszow University of Technology (Poland)
}

\title{
INFORMATION AND PROTECTION POLICY IN THE CONTEXT OF CONSUMER ADVOCACY SOLUTIONS IN THE POLISH LIFE INSURANCE MARKET
}

\begin{abstract}
The article deals with the issues related to the Polish life insurance market in the context of applied information and protection policy solutions. The role of applying a new approach to protect consumer rights in the insurance market is highlighted. The importance of setting new regulatory standards and practices on the part of supervisory authorities has been emphasized in order to increase the transparency of products and the application of certain solutions or the prohibition or limitation of the sales of certain insurance. On the basis of data from the security institutions, the main problems of the Polish life insurance market from the perspective of consumers have been presented and the practices necessary to protect clients are identified.
\end{abstract}

Keywords: life insurance market, consumer protection

\section{Introduction}

In the period of growing discontent resulting from insufficient consumer protection in the life insurance market, especially in relation to investment opportunities, insurers' information policies and insurance awareness have implications for the entire insurance market and the issue of protection of consumer rights and interests is gaining momentum.

The new approach to the protection of purchasers of insurance services and the strengthening of regulatory and supervisory activities in this area, which is the consequence of transformations in the regulatory and supervisory paradigm throughout the financial sector, is of particular importance. When diagnosing market issues from a consumer perspective, it should be emphasized that the potential for consumer advocacy for information and protection policies is a new challenge for the insurance industry as a whole, and for supervisory and security institutions to ensure an adequate level of protection for the life insurance market.

The aim of the study is to present the reasons for the major changes in the principle of the highest trust in the insurance market and the main problems of the life insurance market from the perspective of consumers, which led to the need for significant intervention by regulators on information obligations of insurers and the application of specific solutions on accessibility to information, with special attention to the so-called transparency.

\section{The importance of information and protection policy in the insurance market}

The changes in the approach of customers and insurers to insurance contracts in the market of business insurance indicate that the principles of trust that the entities operating in these markets have used so far, have undergone significant evolution. The original conception of the highest trust in insurance was due to both the difference in the insurance contract and to the fact that the contract was so special that it required both parties to adhere to the principles of the highest trust ${ }^{1}$.

The main reason for the major changes in the principle of the highest trust in recent years is primarily different from the original forms of the process of acquiring information, which changed radically from the beginning of the operation of the

${ }^{1} \mathrm{~J}$. Lowry, Whither the duty of good faith in $U K$ insurance contracts, Connecticut Insurance Law Journal 2009, vol. 16.1, p. 110. 


\section{A. Ostrowska-Dankiewicz.}

first insurance contracts. In today's increasingly conscious world, as a result of activities undertaken mainly by EU legislation, there is a need for significant interventions by supervisory authorities with regard to the information obligations of insurers and the application of specific solutions on information accessibility, with particular reference to the so-called transparency.

Transparency is related to the general principles of the functioning of the financial and insurance market as well as to the way information is to be performed, which is reflected in the requirements for the creation of contractual consumer protection patterns in the insurance services market, reflected in the numerous EU directives ${ }^{2}$.

They use the notion of transparency with regard to the information obligations of insurers in insurance service delivery processes, in line with the concept commonly referred to as the right to information. On the other hand, their primary goal is to equalize the chances of the weaker side of the insurance market and the existing insufficient information of the covered insurance entities. Although the solution deals with the purchasers of insurance services, their more universal character should be emphasized in relation to the imposition of obligations on the insurers to maintain transparency towards all policyholders and insured persons.

The discussion, which is conducted both among practitioners and scientists in the field of transparency, rather than its lack, is causing and deepening the threat to consumer safety in the insurance market, hence the essence of the problem is the right information policy. Information is necessary for both parties to the insurance contract in order to make an informed decision regarding the conclusion of the contract on the terms and conditions specified therein. On the one hand there is a professional entity (insurer or insurance broker) characterized by a distinct advantage over purchasers (policyholders, insured), which are the

${ }^{2}$ K. Malinowska, Transparentność w umowie ubezpieczenia - przemiana zasady najwyższego zaufania $w$ prawo do informacji [in:] Informacja $w$ prawie ubezpieczeń gospodarczych, ed. B. Gnela, M. Szaraniec, LEX Wolters Kluwer business, Warszawa 2015, pp. 2930 . weaker side of the market and the insurance relationship.

Protection of the weaker side of the market through information is based on the assumption that the existing market imbalance between the parties to insurance contracts can be effectively offset by imposing a stronger obligation to disclose information relevant for the policyholder to make a rational decision on the conclusion of the insurance contract ${ }^{3}$.

\section{Protection of consumers' rights in the insurance market in the new financial market regulation and supervision paradigm}

Since the onset of the global insurance market, the issue of protection of consumer rights and their interests has never been the subject of such intense discussion as it is today. Undoubtedly, the introduction of a new regulatory and supervisory paradigm in the financial sector, as a consequence of the 2007-2010 crisis, has led to significant changes in regulatory standards and practices.

When analyzing trends in the fundamentals of financial markets regulation, it should be pointed out that in the 1980s, an old paradigm called the Washington Consensus ${ }^{4}$, based on the belief in the absolute rationality of financial markets, which may be subject to short-lived turbulence, but their proper functioning only required good access to information. Consequently, this consensus was based on the belief that this system was safe thanks to private risk management at the level of individual financial institutions, and the guarantees of the quality of this management were to be verified solely by public financial supervisory systems without external relations.

The crisis, that has hit the global financial markets, has shown that the rationality of markets and financial institutions based solely on trust, transparency and individual risk management has

3 M. Szaraniec, Ochronne reżimy adresata informacji jako słabszej strony stosunku ubezpieczenia, [in:] Informacja $w$ prawie ubezpieczeń gospodarczych, ed. B. Gnela, M. Szaraniec, LEX Wolters Kluwer Business, Warszawa 2015, s. 36-37.

${ }^{4}$ E. Helleiner, A Bretton Woods Moment? The 2007-2008 crisis and the future of global finance, "International Affairs", vol. 86, iss. 3 (May 2010), pp. 619-636. 


\section{Information and Protection Policy in the Context of Consumer Advocacy Solutions...}

turned out to be unreliable, both for the small and the largest market institutions, and hence they started seeking new security policy solutions. The starting point for creating a new consensus, called the Basel one, after the crisis, is to assume that the financial market is fragile and cyclical, with a tendency for herd behavior, which requires the introduction of appropriate policies and the intervention of public institutions by banning certain measures or banning or limiting sales of certain products.
Therefore, in the Basel consensus the so-called macro-prudential supervision based on public risk management of the whole financial system, is crucial. Thanks to this financial security is becoming a public sphere 5 . In addition, the protection of the consumer, an important component of the supervisory system, has become a distinguishing feature of the Basel system. The characteristics of the old and the new regulatory and supervisory consensus of financial markets are summarized in table 1.

Table 1

Characteristics of regulatory-supervisory consensus of financial markets

\begin{tabular}{|c|c|c|c|}
\hline Areas & Perception of financial markets & Impact instruments & Supervision characteristics \\
\hline $\begin{array}{c}\text { Washington } \\
\text { Consensus }\end{array}$ & $\begin{array}{l}\text { - rational, wise and self- } \\
\text { correcting, } \\
\text { - corporate governance and } \\
\text { business models as a } \\
\text { consequence of free private } \\
\text { choice, } \\
\text {-financial innovation is an } \\
\text { important component of financial } \\
\text { security and stability. }\end{array}$ & $\begin{array}{l}\text {-enhanced } \\
\text { transparency, } \\
\text { - private risk } \\
\text { management, } \\
\text { - market discipline } \\
\text { supported by } \\
\text { regulation. }\end{array}$ & $\begin{array}{l}\text { - micro-prudential perspective } \\
\text { - formal and superficial } \\
\text { supervision, } \\
\text { - isolated from politics, } \\
\text { - security is a private domain. }\end{array}$ \\
\hline $\begin{array}{c}\text { Basel } \\
\text { Consensus }\end{array}$ & $\begin{array}{l}\text { - cyclical, unreliable, no } \\
\text { guarantee of self-repair, } \\
\text { - corporate governance and } \\
\text { business models are subject to } \\
\text { public scrutiny, } \\
\text { - financial innovation can } \\
\text { destabilize the financial system. }\end{array}$ & $\begin{array}{l}\text { - enhanced supervisory } \\
\text { powers, } \\
\text { - regulatory discipline } \\
\text { supported by the } \\
\text { market, } \\
\text { - public financial risk } \\
\text { management. }\end{array}$ & $\begin{array}{l}\text { - macro-prudential perspective, } \\
\text { - material and deep supervision, } \\
\text { - penetration by politics, } \\
\text { - security is a public domain, } \\
\text { - consumer protection is an } \\
\text { important component of the } \\
\text { supervisory system. }\end{array}$ \\
\hline
\end{tabular}

Source: J. Monkiewicz, M. Monkiewicz, Tendencje rozwoju ochrony konsumentów na rynku ubezpieczeniowym. Nowe koncepcje i rozwiazania, „Rozprawy Ubezpieczeniowe”, Journal 18 (1/2015), p.7.

Next to the emphasis on macro-prudential perspective is the creation of a separate consumer protection watchdog, which has found its practical appeal in the creation of several European institutions such as the European Banking Authority (EBA), the European Insurance and Occupational Pensions Authority (EIOPA) and the European Securities and Markets Authority (ESMA), whose key tasks are protecting consumer interests in financial services, including insurance and creation of pro-consumer policies in all EU countries.

The resulting system of supervision over financial markets has made use of the precautionary principle. The Financial Services Action Plan has received considerable political support, resulting in a European recovery plan to restore and maintain financial market stability ${ }^{6}$. All these initiatives undertaken by the European Union have led to the creation of a European Financial Supervision Authority (ESFS), which was also involved in overseeing national and macro-prudential oversight.

The basic consumer protection objectives are based on ensuring transparency, simplicity, access to the insurance market and the integrity of the

5 J. Monkiewicz, M. Monkiewicz, Tendencje rozwoju ochrony konsumentów na rynku ubezpieczeniowym. Nowe koncepcje $i$ rozwiazania, „Rozprawy Ubezpieczeniowe", Journal 18 (1/2015), pp. 6-7.

${ }^{6}$ M. Kawiński, Ochrona konsumenta $w$ agendzie Europejskiego Nadzoru Ubezpieczeń $i$ Funduszy Emerytalnych. Kierunki zmian [in:] Ochrona konsumentów na rynku ubezpieczeniowym w Polsce, pod red. J. Monkiewicza i M. Orlickiego, Wyd. Poltext, Warszawa 2015, p. 187. 


\section{A. Ostrowska-Dankiewicz}

parties involved in the consumer relationship. The EIOPA strategy indicated that the following objectives should be met:

1) create conditions for consumers to make informed choices,

2) create a framework for proper sales practices,

3) create conditions for better management of insurance products and their availability and suitability,

(4) promote the development of effective dispute resolution systems,

(5) support the development of insurance guarantee schemes to protect insured against the risk of insolvency of insurance companies.

\section{Main problems of the Polish life insurance market from the perspective of consumers}

Taking into account the relationship and the degree of confidence of clients in the Polish insurance market it should be emphasized that in recent years, especially due to inadequate practices in the sale of investment life insurance products, the rules within so-called product intervention as one of the basic consumer protection instruments are becoming of great importance ${ }^{7}$. By pointing to the reasons for the negative customer approach to certain products, resulting from both their design and low profitability, and the sales policy used by insurers, it is possible to diagnose essential market issues from a consumer perspective. It is of particular importance to obtain accurate information on the effectiveness of life insurance products, especially in the face of growing threats arising from high levels of difficulty, or even lack of access to information about these products (especially their emissions and their effectiveness). This may lead to further negative evaluation of products by market participants, which is reflected in the allegations raised in complaints to the Financial Ombudsman. By observing their numbers and their share in recent years, consumers have been reporting more and more comments on savings products, as summarized in table 2 .

7 For more see: J. Łańcucki, Interwencja produktowa jako instrument ochrony konsumentów w sektorze ubezpieczeń, [in:] Ubezpieczenia we współczesnym świecie. Problemy i tendencje pod red. I. Kwiecień, Wydawnictwo UE we Wrocławiu, Wrocław 2017, pp. 128-136.

Table 2 Number of consumers' complaints
to the Financial Ombudsman

\begin{tabular}{|l|c|c|c|}
\hline \multirow{2}{*}{ Specification } & \multicolumn{3}{|c|}{ No. of complaints } \\
\cline { 2 - 4 } & 2014 & 2015 & 2016 \\
\hline $\begin{array}{l}\text { Lower value of the policy } \\
\text { buyout }\end{array}$ & 123 & 226 & 432 \\
\hline Incorrect policy management & 25 & 23 & 26 \\
\hline Tardiness in policy buyout & 5 & 10 & 1 \\
\hline $\begin{array}{l}\text { Refusal to redeem the policy } \\
\text { value }\end{array}$ & 12 & 13 & 16 \\
\hline $\begin{array}{l}\text { Oddalenie roszczenia } \\
\text { Dismissal of the claim }\end{array}$ & 1701 & 1866 & 2279 \\
\hline $\begin{array}{l}\text { Dispute over the amount of } \\
\text { benefit granted }\end{array}$ & 480 & 517 & 842 \\
\hline $\begin{array}{l}\text { Tardiness in winding-up } \\
\text { proceedings }\end{array}$ & 78 & 76 & 31 \\
\hline $\begin{array}{l}\text { Contributions: amount, } \\
\text { refund, call for payment, etc. }\end{array}$ & 1299 & 753 & 585 \\
\hline $\begin{array}{l}\text { Refusal of continuation of } \\
\text { insurance }\end{array}$ & 20 & 30 & 29 \\
\hline $\begin{array}{l}\text { Procedures used by the } \\
\text { insurance company }\end{array}$ & 36 & 43 & 32 \\
\hline Refusal to inspect the file & 22 & 149 & 56 \\
\hline Change of the insurance sum & 5 & 2 & 5 \\
\hline $\begin{array}{l}\text { Change in GIC during } \\
\text { contract term }\end{array}$ & 10 & 3 & 11 \\
\hline
\end{tabular}

Source: Own study based on data from the Financial Ombudsman's Office.

An increasing number of claims and complaints among consumers of Insurance Capital Funds life insurance show great dissatisfaction with these products. At the end of 2016 they occupied a high position in the group of complaints. In Section I, as many as 1053 applications concerned group 3 insurance. The most frequently cited claims against life insurance insurers were the refusal of a claim by an insurance company, a dispute about the amount of the claim, overdue claims settlement; low or total refusal to pay the policy value and high liquidation fees in case of resignation from ICF life insurance contract

\section{Practices applied in the field of consumer protection in the Polish life insurance market}

The actions taken in recent years by the supervisory and protection institutions in the financial market, including insurance, expressed in particular in the legislative texts, aim at eliminating the problems that concern the offer of life insurance products. The increasing number of complaints and claims reported by the clients of the lack of transparency in the presentation of the properties of savings and 


\section{Information and Protection Policy in the Context of Consumer Advocacy Solutions...}

investment products and the different possibilities of their profitability, or the misselling ${ }^{8}$ phenomenon, led to the need to make changes in the law. They aim to tighten regulations on the safety of the financial market clients and intensify the controls on their compliance by both financial supervisors and consumer ombudsmen.

Thanks to the cooperation of EIOPA with national supervisors and stakeholders, it is possible to obtain information on consumer trends, which is then published in the report of the Department of Finance for Innovation and Consumer Protection. This includes the number of complaints, sales volume, implementation of modern solutions in products and sales, as well as other signals from the market. Previously collected reports allowed to build statistics on the most common causes of consumer complaints. These include: unsatisfactory benefits received, slow referrals, errors in settlement and incompatible return rates (in case of investment products).

There were also many complaints about customer service, breach of privacy regulations, incorrect or incomplete documentation, and the lack of access to the on-line platform. National supervisors also pointed to a number of problem areas, including: the spread of online comparables, price competition, the delivery of erroneous or incomplete information to consumers, the complexity of structured products, the reservations regarding the sale and servicing of mobile phone insurance and bank accounts.

For most life insurance products, whose structure is complex, such as portfolio-based financial instruments or complex investment strategies, the most common problem is the transparency gap in the structure itself. This is due to both lack of standardization at the product development stage and deliberate lack of information on the composition of the instrument or investment strategies. Financial advisors providing cash allocation services at the stage of concluding the contract should provide advice and customer awareness of the investment and savings opportunities as well as customer rights under consumer protection provisions for financial services. In fact, they are most often linked by capital or through commission schemes with financial institutions, hence their informational policy is generally unreliable and,

${ }^{8}$ For more see: J. Cichorska, Misseling, czyli sprzedaz niepotrzebnych instrumentów finansowych i jej skutki. Stan prawny w Polsce $i$ Wielkiej Brytanii, Journal of Insurance, Financial Markets \& Consumer Protection", No. 24 (2/2017), pp. 18-34. as a result, the information provided to the client is non-exhaustive and non-objective ${ }^{9}$.

One also needs to pay attention to situations when the risk of customer ignorance increases, for example by purchasing a distance policy (via the Internet, telephone, etc.) or someone else's account. Simplification of the contract by electronic means influences the decisions of consumers who, by clicking on the appropriate commands displayed on the screen, are driven by impulses and often make ill-considered decisions ${ }^{10}$.

According to the Polish Financial Supervision Authority's ${ }^{11}$ guidelines on insurance distribution, based on Polish legal acts, the functioning of a reliable information policy by insurers is regulated in the guidelines of the supervisory authority of the Polish insurance market, the insurance company should "note in the documentation" that the client has read all the factors that affect their decision to join the insurance contract. If the "record in the documentation" means the client's signature, then there is a problem with remote contracts, or someone else's account where this procedure seems to be quite difficult. Still, it does not relieve the insurer from a fair presentation of the terms of its cooperation.

Any information about the characteristics of the product, such as the scope or object of protection, should be included in the information material and then communicated to the customer. However, the material should also include clearly and transparently presented issues of possible restrictions and exclusions, i.e. situations in which an insurance company limits the payment of benefits or compensation or does not pay them in general. Similarly, in the case of investment products, the insurer should inform about the real risks associated with the investment, as well as the fees which may also become the burden of the policyholder. The information material, as well as the general terms of insurance, and all contract terms

9 B. Frączek, Deficyt transparentności informacji dotyczacej produktów oszczędnościowo-inwestycyjnych jako zagrożenie bezpieczeństwa konsumenta na rynku ustug finansowych, ,Journal of Insurance, Financial Markets \& Consumer Protection", No. 24 (2/2017), p. 42.

${ }^{10}$ I. Adrych-Brzezińska, Obowiazek informacyjny $w$ umowach ubezpieczenia zawieranych na odległość $z \quad$ udziałem konsumentów, "Wiadomości Ubezpieczeniowe" 2015 no. 2, pp. 20-21.

11 Insurance distribution guidelines annexed to Resolution No. 184/2014 of the Polish Financial Supervision Authority dated 24 June 2014 (Official Journal of the Polish Financial Supervision Authority, item 13). 


\section{A. Ostrowska-Dankiewicz}

should be made available to the consumer in the paper or electronic form.

The final point of the Insurers' Information Policy Guidelines includes a recommendation for a product card. It is not an integral part of the contract but is the previously mentioned information material that the distributor should use when selling the product. The product card contains the purpose, characteristics and the whole mechanism of functioning of the insurance.

The provision of Article 15 of the Insurance and Reinsurance $\mathrm{Act}^{12}$, which provides for a broader obligation to unequivocally and comprehensively formulate insurance contracts, not only for contracts and general terms of insurance, but also for all other contractual models, serves undoubtedly as a factor which improves client's situation. On the one hand, regulation improves customer safety and, on the other one, is aimed at increasing product interventions, which can be a very important instrument for consumer protection in the life insurance market. The principles of this intervention are covered by EU regulations, which provide wider market monitoring, including investment products.

\section{Conclusions}

In the last few years, the financial market, including the insurance branch, has seen a tendency for changes in the creation of insurance services. Particular attention should be paid to the application of specific solutions within the information policy of insurers, under the emphasis on increasing the transparency of products in terms of information obligations. These measures, on the one hand, are the result of the recent crisis in the financial markets and the change in the approach to consumer protection supervision. On the other hand, they are also the consequence of inadequate practices used by insurers to sell products for life, especially those associated with investment opportunities.

In order to avoid the aggravation of negative phenomena related to difficulties or lack of information on insurance services, the regulatory and supervisory activities of financial market institutions should be extended, with particular emphasis on forcing insurers as stronger players in insurance distribution practices, thus leading to increased protection. and customer security, which will help eliminate major market issues in the future.

12 Act of 11 September 2015 on insurance and reinsurance business (Journal of Laws 2016, item 1844).

\section{References}

1. Adrych-Brzezińska I., Obowiazek informacyjny $w$ umowach ubezpieczenia zawieranych na odległość $z$ udziałem konsumentów, "Wiadomości Ubezpieczeniowe" 2015 no. 2, p. 20-21.

2. Cichorska J.,, Misseling, czyli sprzedaż niepotrzebnych instrumentów finansowych $i$ jej skutki. Stan prawny w Polsce $i$ Wielkiej Brytanii, Journal of Insurance, Financial Markets \& Consumer Protection", No. 24 (2/2017).

3. Fraczek B., Deficyt transparentności informacji dotyczacej produktów oszczędnościowoinwestycyjnych jako zagrożenie bezpieczeństwa konsumenta na rynku ustug finansowych, ,,Journal of Insurance, Financial Markets \& Consumer Protection”, No. 24 (2/2017).

4. Helleiner W., A Bretton Woods Moment? The 2007-2008 crisis and the future of global finance, „International Affairs”, vol. 86, iss. 3 (May 2010).

5. Kawiński M., Ochrona konsumenta $w$ agendzie Europejskiego Nadzoru Ubezpieczeń i Funduszy Emerytalnych. Kierunki zmian [in:] Ochrona konsumentów na rynku ubezpieczeniowym w Polsce, pod red. J. Monkiewicza i M. Orlickiego, Wyd. Poltext, Warszawa 2015.

6. Lowry J., Whither the duty of good faith in UK insurance contracts, Connecticut Insurance Law Journal 2009, vol. 16.1.

7. Łańcucki J., Interwencja produktowa jako instrument ochrony konsumentów w sektorze ubezpieczeń, [in:] Ubezpieczenia we wspótczesnym świecie. Problemy $i$ tendencje pod red. I. Kwiecień, Wydawnictwo UE we Wroctawiu, Wroctaw 2017, pp. 128-136.

8. Malinowska K., Transparentność $w$ umowie ubezpieczenia - przemiana zasady najwyższego zaufania $w$ prawo do informacji [w:] Informacja $w$ prawie ubezpieczén gospodarczych, ed. B. Gnela, M. Szaraniec, LEX Wolters Kluwer Business, Warszawa 2015.

9. Monkiewicz J.,Monkiewicz M., Tendencje rozwoju ochrony konsumentów na rynku ubezpieczeniowym. Nowe koncepcje $i$ rozwiazania, „Rozprawy Ubezpieczeniowe", Zeszyt 18(1/2015).

10. Szaraniec M., Ochronne reżimy adresata informacji jako stabszej strony stosunku ubezpieczenia, [in:] Informacja w prawie ubezpieczeń gospodarczych, red. B. Gnela, M. Szaraniec, LEX Wolters Kluwer Business, Warszawa 2015.

11. Act of 11 September 2015 on insurance and reinsurance business (Journal of Laws 2016, item 1844).

12. Wytyczne dotyczqce dystrybucji ubezpieczeń, stanowiace załacznik do uchwaty $\mathrm{Nr}$ 184/2014 Komisji Nadzoru Finansowego z dnia 24 czerwca 2014 r. (Dz. Urz. KNF poz. 13). (Insurance distribution guidelines annexed to Resolution No. 184/2014 of the Polish Financial Supervision Authority dated 24 June 2014 (Official Journal of the Polish Financial Supervision Authority, item 13). 